\title{
Distribution and ecology of the stoneflies (Plecoptera) in Catalonian rivers (NE-Spain)
}

\author{
M.A. Puig1
}

Since 1978 a sampling program is being conducted on various basins of Catalonia (NE-Spain), covering the whole of the basins of the rivers Tordera, Llobregat, Besos, Ter, Foix and Segre (Andorran rivers included).

A total of 51 species of Plecoptera has been collected in a range of altitudes from $100 \mathrm{~m}$ to $2250 \mathrm{~m}$. Among them, there are stenothermal species of high altitude and a group of species that live in temporary water courses. Some species of Leuctridae, Capniidae and Chloroperlidae are members of the interstitial fauna in some instars of their life.

Distribution et écologie des Plécoptères dans des rivières catalanes (Nord-Est de I'Espagne).

Nous avons commencé en 1978 un programme extensif pour connaître les macro-jnvertébrès des bassins de Catalogne (Nord-Est de l'Espagne). Cette étude porte sur les bassins des rivières Tordera, Llobregat, Besòs. Ter, Foix et Segre (y compris les rivières d'Andorre).

Nous avons récolté 51 espèces de Plécoptères entre 100 et $2250 \mathrm{~m}$ d'altitude. Certaines de ces espèces sont des sténothermes de haute altitude, d'autres habitent des ruisseaux temporaires des Pyrénées ou du littoral méditerranéen. Quelques especes de Leuctridae. Capniidae et Chloroperlidae vivent en milieu interstitiel à certains stades de leur cycle.

\section{1. - Introduction}

The Ecology Department of the University of Barcelona has a research program centered on river ecosystems. As a part of this general work, it was necessary to study extensively the macrobenthic fauna and the physico-chemical characteristics of the Catalonian river basins. In this work, the results of prospections in the rivers Llobregat, Besòs. Foix, Tordera, Ter and Segre (Andorran basins included) are presented. The data concerning the river Ter are only of a preliminary nature, as this work is still incomplete. 225 stations have been studied and Plecoptera have been found in 118 (Fig. 1).

\section{2. - The environment}

Two of the rivers studied arise in the Pyrenees (Ter and Segre), one in the Pre-Pyrenees (Llobregat)

1. Department of Ecology. University of Barcelona, Av. Diagonal 645, Barcelona - 28. Spain. and three in the Pre-Littoral mountains (Besos, Tordera and Foix). Morphometric and physico-chemical data and localisation of the sampling stations are given in Prat et al. (1979, 1982 and 1983). Extreme pollution of stretches of our rivers excludes Plecoptera from rivers of a order higher than three (on 1 : 250000 maps).

\section{3. - Species distribution according to different parameters}

\section{1. - Altitude}

Fifty one species have been captured between 105 and $2249 \mathrm{~m}$. Table I shows that the altitudinal ran. ges of each species are not the same in the different basins. Conditions in the river Tordera are similar to those in the Pyrenean and Pre-Pyrenean upper reaches and catchment areas of the rivers Segre, Llobregat and Ter.

The altitudinal substitution among different species inside each of the larger groups, as observed 


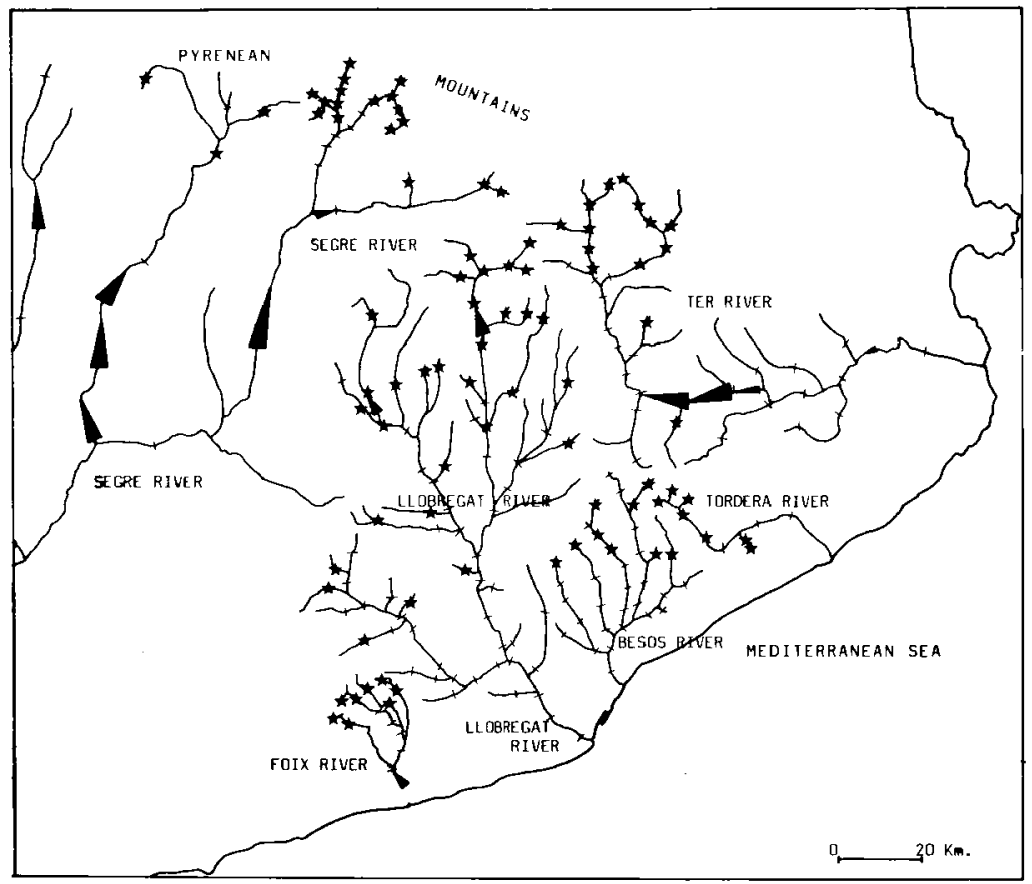

Fig. 1. Distribution of sampling stations in Catalonia. All the sampling stations in Andorra (50) are not shown. Stoneflies have been found in all the stations marked with an asterisk $\left(^{*}\right)$.

by Berthélemy (1966), has been confirmed. Perlodes microcephalus, Leuctra major and L. fusca reach $2000 \mathrm{~m}$. Euleucira geniculata has been found between 250 and $1000 \mathrm{~m}$, and Leuctra despaxi was found in lower altitudes than those from which it was recorded by Berthélemy (1966).

\section{2. - Substrates}

In the river Ter, Capnia vidua, Leuctra major and L. leptogaster and the early instars of Taeniopteryx schoenemundi and Siphonoperla torrentium have been found as components of the interstitial fauna. In river Tordera, early instar of Capnioneura mitis, $B$ rachyptera risi and $B$. brauer live in similar habitats. B. risi and B. braueri, in their last instars, are normally inhabitants of dead leaves and vegetal detritus retained on the stream bed; so is Taeniopteryx hubaulti. The last instars of Euleuctra geniculata appear preferently associated with Cladophora. Nemurella pictetii has been found only amongst mosses. Nemoura cinerea cinerea occurs amongst mosses and filamentous algae, and in its last instars, before the emergence, it gathers sometimes on the Characeae. 
Table I. Altitudinal distribution of the stoneflies in the Catalonian basins.

\begin{tabular}{|c|c|c|c|c|c|c|}
\hline SPECIES & Segre & Ter & Llobregat & Tordera & Besós & Foix \\
\hline $\begin{array}{l}\text { Taeniopteryx hubaulti Aubert, } 1946 \\
\text { T. schoenemundi (Mertens, 1923) }\end{array}$ & 1500 & 470 & & & & \\
\hline Brachyptera braueri (Klapálek, 1900) & & & & 105 & & \\
\hline B. risi (Morton, 1896) & & 1100 & $745-980$ & 105 & & \\
\hline B. seticomis (Klapálek, 1902) & & 1100 & & & & \\
\hline Protonemura beatensis Despax, 1929 & $900-2080$ & $860-1000$ & $650 \cdot 1360$ & 390 & 1000 & \\
\hline P. intricata intricata (Pictet, 1842) & $900-1960$ & & & 680 & 340 & \\
\hline P. meyeri (Pictet, 1894) & & $470-950$ & & $680-700$ & 1000 & \\
\hline P. praecox (Morton, 1894) & & & & 680 & 1000 & \\
\hline P. pyrenaica pyrenaica Mosely. 1930 & 1407 & $915-1300$ & & 680 & & \\
\hline P. pyrenaica asturica Aubert, 1954 & & & & & & $250-625$ \\
\hline P. risi spinulosa (Navás, 1921) & $960-1780$ & 2100 & 1360 & 680 & & \\
\hline P. vandeli Berthélemy, 1963 & $1140-2080$ & $1100-2100$ & 1000 & 680 & & \\
\hline Amphinemura sulcicollis sulcicollis (Stephens, . & & & & & & \\
\hline 1835) & $1360-1680$ & $915-1300$ & $720-980$ & $390-720$ & $420-1000$ & \\
\hline A. triangularis Ris, 1902 & & & & 680 & & \\
\hline Nemoura cinerea cinerea Retzius, 1783 & & & $180-740$ & 105 & $560-570$ & $310-525$ \\
\hline N. erratica Claassen, 1936 & $1680-2040$ & & & & & \\
\hline N. lacustris Pictet, 1865 & & & & & & 625 \\
\hline N. linguata Navás, 1918 & 1140 & & $392-420$ & & & \\
\hline N. ct. mortoni Ris, 1902 & & $470-1000$ & & & 1000 & \\
\hline N. uncinata Despax, 1934 & 2020 & $740-1300$ & & 720 & & \\
\hline Nemurella picterii Klapálek, 1909 & $1900-2080$ & & & & $320-340$ & \\
\hline Euleuctra geniculata Stephens, 1835 & & 950 & $350-800$ & & $250-340$ & \\
\hline Leuctra alosi Navás. 1919 & 1140 & & & & & \\
\hline L. aurita Navàs, 1919 & $960-2040$ & 1300 & 640 & 680 & & \\
\hline L. despaxi Mosely. 1930 & & 1300 & & 240 & & \\
\hline L. fusca (Linné, 1758) & 1900 & & 480 & & & \\
\hline L. hippopus Kempny, 1899 & & & $425-980$ & & 340 & \\
\hline L. inermis Kempny, 1899 & $1060-1800$ & $1100-1300$ & $285-1360$ & & 1000 & \\
\hline L. leptogaster Aubert, 1949 & 950 & 950 & $480-550$ & & & \\
\hline L. major Brinck, 1949 & $1140-2000$ & & & 680 & & \\
\hline Pachyleuctra benlocchi (Navás, 1917) & 1780 & 2100 & & & & \\
\hline P. berirandi Aubert, 1952 & & 1100 & & & & \\
\hline Capnia bifrons (Newman, 1838) & & & & 105 & & \\
\hline C. vidua Klapálek, 1904 & & & $326-740$ & & & . \\
\hline Capnioneura brachyptera Despax, 1932 & $1660-2020$ & & & & & \\
\hline C. mitis Despax, 1932 & & & 326 & $105-240$ & 560 & 505 \\
\hline $\begin{array}{l}\text { Arcynopteryx compacta (MacLachlan, 1872) } \\
\text { Perlodes intricarus (Pictet 1842) }\end{array}$ & $\begin{array}{l}2249 \\
2040\end{array}$ & 2100 & & & & \\
\hline P. microcephalus (Pictet, 1842) & $1800-2040$ & & & & 340 & \\
\hline Isoperla acicularis acicularis (Despax, 1936) & $1180-1800$ & & & 680 & & \\
\hline Isoperla d. & $1260-1760$ & $740-1300$ & 1360 & & & \\
\hline I. grammatica sp. $I V$ & & & $380-800$ & $105-240$ & $320-660$ & \\
\hline I. moselyi (Despax, 1936) & 2000 & & & & & \\
\hline l. cf. viridinervis (Ed. Pictet, 1865) & 1340 & & & & & \\
\hline Dinocras cephalotes (Curtis, 1827) & $780-1360$ & $780-1300$ & $480-800$ & & & \\
\hline Perla grandis Rambur & $1160-1740$ & 1300 & & & & \\
\hline P. marginata marginata (Panzer, 1799) & $780-1360$ & $990-1000$ & $540-980$ & $240-700$ & $340-420$ & \\
\hline Chloroperla tripunctata (Scopoli, 1763) & $1800-1960$ & & & & & \\
\hline Xantoperla apicalis (Newman, 1837 ) & 1140 & & & & & \\
\hline Siphonoperla torrentium (Pictet, 1842) & $1140 \cdot 1800$ & 1300 & & $105-680$ & 1000 & \\
\hline
\end{tabular}




\section{3. - Physico-chemical characteristics}

Euleuctra geniculata has been found only in calcareous areas. Nemoura lacustris and Protonemura pyrenaica asturica live in streams that dry up in sum. mer. Capnioneura mitis and Nemoura c. cinerea have been found also in the same streams but also in others which dry up less frequently. In the latter also occur Brachyptera brateri, $B$. risi, $B$. seticomis and Capnia bifrons.

The Plecoptera are not tolerant, in general, to organic and industrial pollutions. The less sensitive species are those living in interstitial water (Capnia vidua and Capnioneura mitis) and in temporary streams (Nemoura c. cinerea and Capnioneura mitis). Isoperla grammatica sp. IV, Dinocras cephalotes and Perla marginata marginata are also quite tolerant.

Most of the 51 species have been found in water at temperatures lower than $15^{\circ} \mathrm{C}$. Five species have been captured in summer at water temperatures between 22 and $27^{\circ} \mathrm{C}$; these are Perla marginata marginata, Dinocras cephalotes, Leuctra inermis, Leuctra hippopus and Euleuctra geniculata.

\section{4. - Discussion}

We have divided our 51 species, into five groups according to their biogeographic distribution (based on Berthélemy's (1966) broad criteria). Twenty eight species are widely distributed in Spain and Europe. Six are Pyrenean endemics (Pachyleuctra benlocchi, Pachyleuctra bertrandi, Isoperla moselyi, Isoperla viridinervis and Isoperla d.). Five inhabit both the Pyrenees and the Iberian peninsula (Protonemura beatensis beatensis, $P$. risi spinulosa, Leuctra despaxi, $L$. alosi and Isoperla grammatica sp. IV). Ten species have not been recorded south of the river Ebro (Protonemura praecox, $P$. pyrenaica pyrenaica, $P$. vandeli, Nemoura linguata, $N$. uncinata, Leuctra digitata, Capnia vidua vidua, Taeniopteryx hubaulti, Perlodes intricatus and Isoperla acicularis acicularis). One species is an endemic from the Iberian penin. sula (Protonemura pyrenaica asturica). According to our findings, Protonemura vandeli, $P$. pyrenaica pyrenaica and Nemoura linguata cannot be considered any more as endemics from the Pyrenees. Taeniopteryx hubaulti is recorded for the first time from the Spanish Pyrenees.

Table II. Distribution of the stoneflies along the Ter and Valira del Nort rivers.

\begin{tabular}{|c|c|c|c|}
\hline $\begin{array}{l}\text { Altitude } \\
\text { (m) }\end{array}$ & Valira del Nort & $\begin{array}{l}\text { Altitude } \\
\text { (m) }\end{array}$ & Ter \\
\hline $\begin{array}{l}2249 \\
2020\end{array}$ & $\begin{array}{l}\text { Arcynopteryx compacta } \\
\text { Protonemura vandeli } \\
\text { Capnioneura brachyptera } \\
\text { Perlodes microcephalus }\end{array}$ & 2100 & $\begin{array}{l}\text { Arcynopteryx compacta } \\
\text { Protonemura vandeli } \\
\text { Protonemura risi spinulosa } \\
\text { Pachyleuctra benlocchi }\end{array}$ \\
\hline 1480 & $\begin{array}{l}\text { Protonemura vandeli } \\
\text { Protonemura beatensis } \\
\text { Isoperla } \text { a. acicularis }\end{array}$ & 1300 & $\begin{array}{l}\text { Leuctra inermis } \\
\text { Isoperla } d . \\
\text { Dinocras cephalotes }\end{array}$ \\
\hline & Perla grandis & 990 & Nemoura uncinata \\
\hline 1360 & Amphinemura s. sulcicollis & & Amphinemura s. sulcicollis \\
\hline 1320 & Leuctra aurita & & Isoperla $d$ \\
\hline 1280 & $\begin{array}{l}\text { Protenemura vandeli } \\
\text { Protonemura beatensis } \\
\text { Isoperla } d .\end{array}$ & 915 & $\begin{array}{l}\text { Perla marginata marginata } \\
\text { Protonemura meyeri } \\
\text { Protonemura p. pyrenaica }\end{array}$ \\
\hline 1260 & Perla grandis & & A, s, sulcicollis \\
\hline 1160 & $\begin{array}{l}\text { Protonemura beatensis } \\
\text { Leuctra aurita }\end{array}$ & & $\begin{array}{l}\text { Nemoura of mortoni } \\
\text { Isoperla } d \text {. }\end{array}$ \\
\hline & Perla grandis & 780 & Dinocras cephalotes \\
\hline 1080 & $\ldots \ldots \ldots \ldots$ & 740 & $\ldots \ldots \ldots \ldots \ldots$ \\
\hline
\end{tabular}


The Plecoptera distribution in the different rivers does not show clear communities. As Berthélemy (1966) noticed, there is a greater similarity among the sampling stations of the same river, than in the similar stations of different rivers (Table II). Each station presents a characteristic community, except in cases of organic pollution, where the population is reduced to one or two species. This is the case of Dinocras cephalotes in Llobregat, Ter and Valira sta. tions and Protonemura beatensis and Leuctra major in Valira d'Orient (Andorra). In the temporary streams, different combinations of the four species Nemoura cinerea cinerea, $N$. lacustris, Capnioneura mitis and Protonemura pyrenaica asturica are present.

The plecopteran fauna of Catalonia is not yet completely known. The research on other basins, on lakes population and on interstitial waters have scarcely begun.

\section{Literature cited}

Berthélemy (C.). 1966. - Recherches écologiques et biogéographiques sur les Plécoptères et Coléoptères d'eau courante (Hydraena et Elminthidae) des Pyrénées. Annls Limn. 2 (2): 227.458 .

Prat (N.), Bautista (M.I), Gonzalez (G.) \& Puig (M.A.). 1979. - La xarxa hidrografica andorrana. In R. Folch (ed.) El patrimoni nalural d'Andorra: 261-277, Barcelona

Prat (N.), Puig (M.A.), Gonzalez (G.) \& Tort (M.J.). 1982. - Predic. ció $i$ conirol de la qualitat de les atgües dels rius Besós $i$ Llo. bregar. I: Els factors físics i quimics del Medi. Estudis i mono grafjes del Servei del Medi Ambient, Diputació de Barcelona. $n^{\circ}$ 6: 204 p. Barcelona.

Prat (N.), Puig (M.A.) \& Gonzalez (G.). 1983. - Predicció i control de la qualitat de les aigües dels rius Besós i Llobregat. II : El poblament faunistic i la seva relació amb la qualitat de les aigïes. Estudis i monografies del Servei del Medi Ambient. Diputació de Barcelona, $n^{\circ}$ 9: 164 p. Barcelona. 